\title{
Relations among Valencia Orange Yields with Soil and Leaf Nutrients in Northwestern Paraná, Brazil
}

\author{
Jonez Fidalski ${ }^{1 *}$, Pedro Antonio Martins Auler ${ }^{1}$ and Valdomiro Tormem ${ }^{2}$ \\ ${ }^{1}$ Instituto Agronômico do Paraná (IAPAR). Caixa Postal 564. CEP 87701-970. Paranavaí-PR, Brazil; \\ EMATER-PR/Paraná Citros S.A. Caixa Postal 28. CEP 87701-970. Paranavaí-PR, Brazil
}

\begin{abstract}
The Valencia orange orchards established on soils of low fertility in the Northwest region of Paraná State, Brazil, have showed symptoms of $\mathrm{Mg}$ deficiency and reduced fruit yields. The objective of this study was to verify the relationship between yield with soil and leaf nutrients during 1996/97 growing season. Two sites of low and high productivity were selected in seven orchards. Leaf and soil samples (fertilized rows and interrows) were collected in 1996. The results showed that the citrus yields were negatively related with soil $\mathrm{Mg} / \mathrm{K}$ and $\mathrm{Ca}+\mathrm{Mg} / \mathrm{K}$ ratios in the fertilized rows, and fruit weight positively correlated with leaf $\mathrm{Zn}$ in the low productivity orchards. The fruit weight was positively related with leaf $\mathrm{Ca}$ and soil $\mathrm{Ca}$ in the fertilized rows of the high productivity orchards. The results suggested an adequate lime and $\mathrm{K}$ fertilization managements in the fertilized rows, as well as an adequate $\mathrm{Zn}$ supply.
\end{abstract}

Key words: Citrus sinensis, foliar diagnosis, liming, $\mathrm{K}$ fertilization, calcium, zinc

\section{INTRODUCTION}

In the last years, orange planting has increased in Paraná State, Brazil, totalling an area of 13,001 ha (SEAB, 1999). About $50 \%$ of the citrus orchards were established in the Northwest region of the State. This region represents $15 \%$ of the total area of the State of Paraná and presents soils originated from Caiuá sandstone with low acidity and fertility (Fidalski, 1997). After five harvests, sweet orange trees (Citrus sinensis (L.) Osbeck) showed symptons of nutritional unbalanced, such as $\mathrm{Mg}$ deficiency and reduced fruit size. Many orchards produced less than 800 boxes ( $40.8 \mathrm{~kg}$ each one) of fruit per hectare, which is considered to be low enough for an economic production in Paraná.

The first nutritional survey of citrus conducted in the State of Paraná (Fidalski \& Auler, 1997) showed that lime applied at planting time (1989-

\section{MATERIALS AND METHODS}

\footnotetext{
* Author for correspondence
}

91) increased soil $\mathrm{Ca}$ and $\mathrm{Mg}$ levels in the first harvest (1992/93 growth season), but there was a decrease afterwards. In 1996, the soil base saturation $(\mathrm{Ca}+\mathrm{Mg}+\mathrm{K} / \mathrm{CECx} 100)$ was about $40 \%$, a level similar to the planting time and insufficient for an economic citrus crop production. In this year, the soil chemical analysis of the fertilized rows showed high acidity and low $\mathrm{Ca}$ and $\mathrm{Mg}$ contents as compared to the interrows. The foliar analysis revealed an adequate supply of $\mathrm{N}, \mathrm{P}$ and $\mathrm{K}$, and high nutritional deficiencies of $\mathrm{Ca}, \mathrm{Mg}$ and $\mathrm{Zn}$. It is concluded that nutritional problems of the citrus orchards are related to inadequate supply of $\mathrm{Ca}, \mathrm{Mg}$ and $\mathrm{Zn}$.

The objective of this study was to verify the relations among Valencia orange yields with soil and leaf nutrients during 1996/97 growing season, in soils originated from Caiuá geological formation of the State of Paraná.

This study was carried out during 1996/97 growing season in the Northwestern Paraná, 
Brazil, between coordinates $22^{\circ} 30^{\prime}-23^{\circ} 30^{\prime} \mathrm{S}$ and $52^{\circ} 00^{\prime}-53^{\circ} 00^{\prime} \mathrm{W}$. The orchards were located at Paranavaí, São João do Caiuá, Alto Paraná, Mandaguaçú, Floraí, Amaporã and Planaltina do Paraná, all within a $50 \mathrm{Km}$ radius of Paraná Citrus Industry from Paranavaí. The soils were Red Dark Latossol and Podzolic with sandy texture and low fertility to depth of $20 \mathrm{~cm}$ (EMBRAPA, 1984; Fidalski, 1997).

Two sites were chosen in seven Valencia orange orchards on Rangpur lime rootstock with 5-7 years old. These sites were studied before by Fidalski \& Auler (1997). It was showed healthy plants, and the fertilizers and lime had been used following the recommendations by GPACC (1994). The yield datas harvest 1995/96, reported by Paraná Citrus orange juice industry at Paranavaí, were employed to select the sites with low and high productivity. Orchard productivity was estimated by the number of boxes with $40.8 \mathrm{~kg}$ fruit per hectare, equivalent to yields of 357 trees in a planting spacing of $4 \mathrm{~m} \times 7 \mathrm{~m}$.
The soil samples were colected in the fertilized rows and in the interrows to a depth of $20 \mathrm{~cm}$ in each site. Ten soil subsamples were taken per site and they were composited to obtain a sample for analysis. Plant nutrition was evaluated by collecting the third and fourth leaves from fruiting branches in four quadrants of ten plants in each site (eighty leaves per sample). Soil and leaf samples were collected in each site of low and high productivity during May-July 1996, following the recommendations by GPACC (1994). The soil and leaf samples were analyzed by regular methods used by the Agronomic Institute of the State of Paraná (Pavan et al., 1992; Miyazawa et al., 1992). The number of fruit boxes per hectare and mean fruit weight were also measured in 1997 by the Paraná Citrus Industry. The soil and leaf nutrient chemical analysis were related to the number of fruit boxes per hectare and mean fruit weight. Data were analyzed using Pearson correlations (SAS, 1990).

Table 1. Average soil chemical characteristcs in Valencia orange orchards of low and high productivity, in the fertilized rows and interrows

\begin{tabular}{|c|c|c|c|c|c|c|c|c|c|c|c|}
\hline Site productivity & $\mathrm{pH}-\mathrm{CaCl}_{2}$ & Al & $\mathbf{H}+\mathbf{A l}$ & $\mathbf{C a}$ & Mg & $\mathbf{K}$ & CEC & $\mathbf{V}$ & $\mathbf{C a}^{(1)}$ & $\mathbf{M g}^{(1)}$ & $\mathbf{K}^{(\mathbf{1})}$ \\
\hline & & & 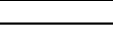 & - mm & $\mathrm{cm}^{-3}-$ & 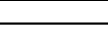 & - & $\longrightarrow$ & ${ }^{c}$ & - & - \\
\hline & \multicolumn{11}{|c|}{ Fertilized rows } \\
\hline Low & 4,8 & 0,6 & 28,8 & 10,6 & 5,6 & 2,7 & 47,6 & 39,5 & 22,3 & 11,9 & 5,2 \\
\hline \multirow[t]{2}{*}{ High } & 4,9 & 0,9 & 28,4 & 10,4 & 6,2 & 1,6 & 46,6 & 39,4 & 22,5 & 13,5 & 3,4 \\
\hline & \multicolumn{11}{|c|}{ Interrows } \\
\hline Low & 5,4 & 0,3 & 24,1 & 12,1 & 8,1 & 1,6 & 45,9 & 46,3 & 25,7 & 17,3 & 3,2 \\
\hline \multirow[t]{2}{*}{ High } & 5,2 & 0,5 & 25,0 & 11,6 & 6,9 & 0,9 & 44,5 & 43,0 & 25,7 & 15,2 & 2,1 \\
\hline & & & & & (2) & (2) & & (3) & (4) & (4) & (5) \\
\hline Adequated levels & $\ldots$ & $\ldots$ & $\ldots$ & $\ldots$ & $>9,0$ & $>2,0$ & $\ldots$ & $>50,0$ & $>40,0$ & $>10,0$ & $<5,0$ \\
\hline
\end{tabular}




\section{RESULTS AND DISCUSSION}

The soil $\mathrm{pH}, \mathrm{H}+\mathrm{Al}, \mathrm{Al}, \mathrm{Ca}, \mathrm{Mg}$, cation exchange capacity (CEC), base saturation (V) and $\mathrm{Ca}$ and $\mathrm{Mg}$ saturation did not show difference between sites of low and high productivity of Valencia orange orchards (Table 1). Only the soil K content showed difference between two sites (Table 1). The levels of soil $\mathrm{K}$ content and the $\mathrm{K}$ saturation in the CEC in the fertilized rows of the low productivity orchards, were higher than the critical valuers of $2 \mathrm{mmol}_{\mathrm{c}} \mathrm{dm}^{-3}$ and $5 \%$, respectively, for citrus production in Brazil (Quaggio, 1996; Malavolta \& Prates, 1994).

The citrus yield was not correlated with a single soil nutrient content, but was correlated with $\mathrm{Mg} / \mathrm{K}$ and $\mathrm{Ca}+\mathrm{Mg} / \mathrm{K}$ ratios in the fertilized rows of the low productivity orchards only (Fig. 1). Quaggio (1996) showed that excess of K fertilization decreased citrus yield in the State of São Paulo. For the Nortwestern region of Paraná, it has been found that $\mathrm{Ca}$ nutrition increased citrus yield in soils originated from Caiuá geological formation (Fidalski et al., 1999a). It is also possible that $\mathrm{Ca}$ and $\mathrm{Mg}$ uptake by plants may be reduced due to the high concentration of soil $\mathrm{K}$ in the fertilized rows (Table 1). This hypothesis is supported due to the strong antagonism among these three cations $(\mathrm{Ca}, \mathrm{Mg}$ and $\mathrm{K})$ observed in the soils for Fidalski et al. (1999a, b).

Relationship analysis (Fig. 2) showed that the fruit weight was positively related with leaf $\mathrm{Zn}$ in the low productivity orchards, while in the high productivity orchards the fruit weight was positively related with leaf $\mathrm{Ca}$ and soil $\mathrm{Ca}$ in the fertilized rows. The fruit weight did not correlated with leaf $\mathrm{K}$ of low and high productivity orchards, $\mathrm{R}=0,19 \mathrm{NS}$ and $\mathrm{R}=0,18 \mathrm{NS}$, respectively. The high $\mathrm{K}$ in the fertilized rows and leaf $\mathrm{Zn}$ deficiency in the low productivity orchards (Tables 1 and 2), were assumed to be the main nutritional factor in reducing fruit size. This is supported by the works published by Malavolta \& Violante Netto (1989), Quaggio (1996), Fidalski \& Auler (1997), and Fidalski et al., (1999a, b).

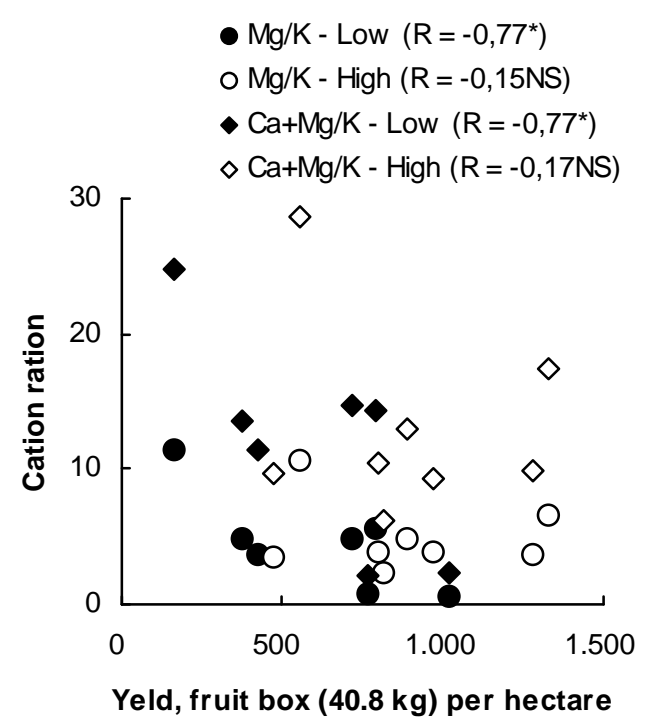

Figure 1. Relationship between yield with cation ration in the fertilized rows of the low and high productivity orchards. NS and * denote not significant and significant at $P \leq 0.05$, respectively.

Table 2. Average leaves nutrients concentrations in Valencia orange orchards of low and high productivity, in relation to the adequate levels from May/July (Malavolta \& Prates, 1994).

\begin{tabular}{|c|c|c|c|c|c|c|c|c|c|c|c|}
\hline Site productivity & $\mathbf{N}$ & $\mathbf{P}$ & $\mathbf{K}$ & $\mathbf{C a}$ & Mg & $\mathbf{S}$ & $\mathbf{Z n}$ & B & $\mathrm{Cu}$ & Mn & $\mathbf{F e}$ \\
\hline & \multicolumn{6}{|c|}{$\longrightarrow \mathrm{g} \mathrm{kg}^{-1} \longrightarrow$} & \multicolumn{5}{|c|}{$\mathrm{mg} \mathrm{kg}^{-1}$} \\
\hline Low & 24,8 & 1,3 & 15,6 & 32,3 & 2,8 & 3,6 & 18,2 & 71,3 & 79,6 & 62,0 & 218,3 \\
\hline High & 25,6 & 1,3 & 16,4 & 33,1 & 2,6 & 3,5 & 17,7 & 66,9 & 93,3 & 68,9 & 156,2 \\
\hline Adequate levels & 22,0 & 1,1 & 10,0 & 30,0 & 2,0 & 2,0 & 25,0 & 60,0 & 10,0 & 25,0 & 150,0 \\
\hline
\end{tabular}


The visual deficiency symptoms of Mg observed in orange orchards in the Nortwestern Paraná may be related with the antagonism among $\mathrm{Ca}, \mathrm{Mg}$ and $\mathrm{K}$ on citrus nutrition (Fidalski \& Auler, 1997; Fidalski et al, 1999a, b). Considering these three cations, the $\mathrm{Mg}$ is considered to be the first nutrient that shows symptoms of nutritional unbalanced in citrus (Malavolta \& Violante Netto, 1989). For the low productivity orchards it is posssible that the normal yearly application of mineral fertilization $(\mathrm{N}, \mathrm{P}$ and $\mathrm{K})$ associated with low lime frequency increased leaching of basic cations in the fertilized rows, specially $\mathrm{Mg}$ (Fidalski \& Auler, 1997) (Table 1).

The results of this citrus nutritional survey showed nutricional problems associated with $\mathrm{Ca}, \mathrm{Mg}$ and $\mathrm{Zn}$ in the low productivity orchards. Similar results have been reported for the citrus orchards in the Nortwestern part of Paraná (Fidalski \& Auler, 1997). The results of the present work suggested the need for an adequate lime and $\mathrm{K}$ fertilization managements in the fertilized rows, as well as an adequate $\mathrm{Zn}$ supply.
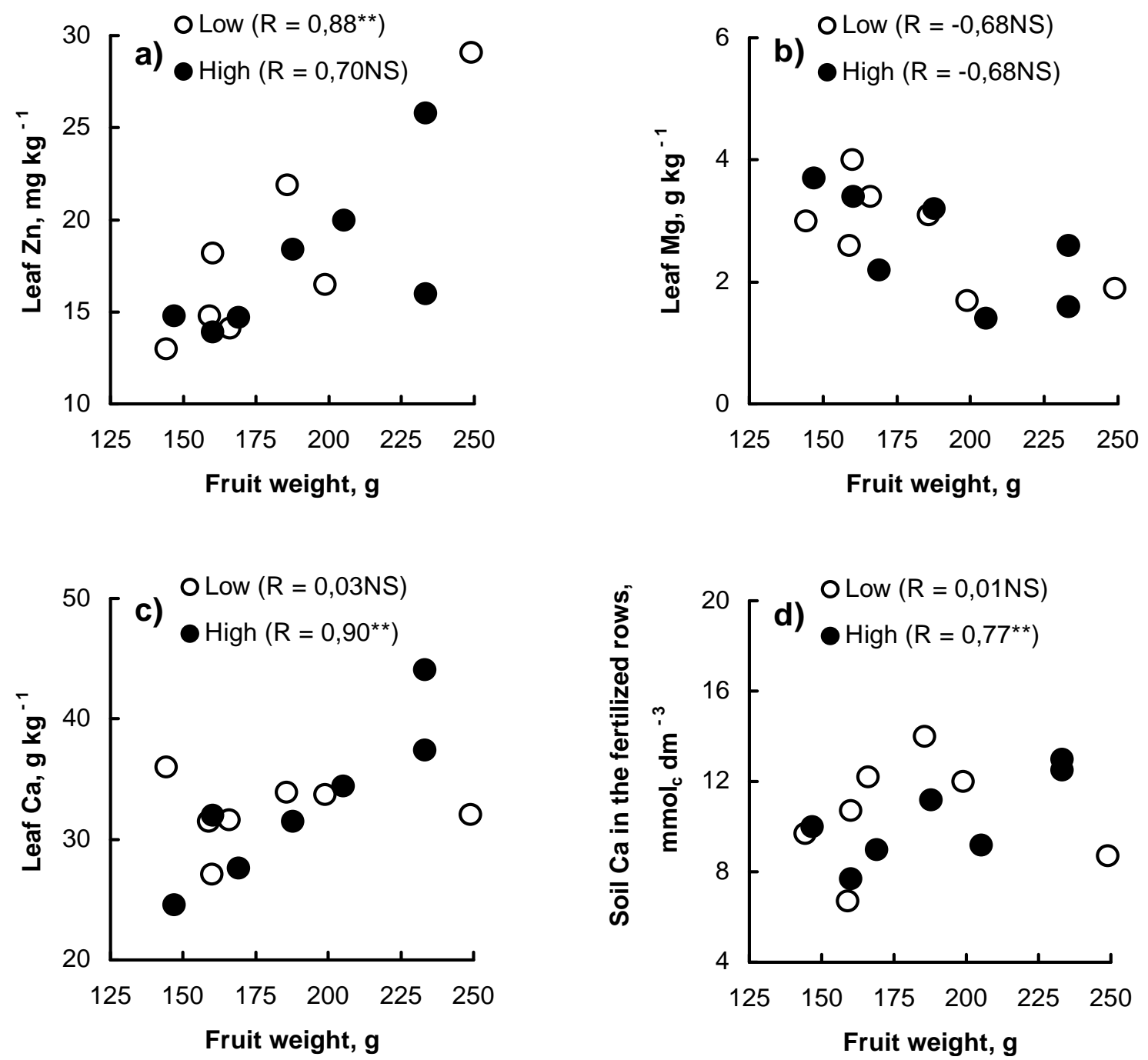

Figure 2. Relationship between fruit weight with the leaf and soil nutrients in Valencia orange orchards of low and high productivity. NS, * and $* *$ denote not significant and significant at $P \leq 0.01$ and $P \leq 0.05$, respectively. 


\section{ACKNOWLEDGEMENTS}

The authors acknowledge Paraná Citrus Industry for provinding the Valencia orange yields in the 1995/96 and 1996/97 growing season. We also are thanks to the Agronomists who colleted soil and leaf samples: José Carlos Fernandes de Souza, Marco Valério Ribeiro, Osmar Ferrari, Agnaldo Conceição da Purificação and Júlio Antonio Costa Daniel. We also wish to thank Dr. Marcos Antonio Pavan, IAPAR for the manuscript review.

\section{RESUMO}

Os pomares de laranja Valência (Citrus sinensis (L.) Osbeck) estabelecidos em solos de baixa fertilidade da região noroeste do Paraná, tem apresentado sintomas de desequilíbrio nutricional, principalmente deficiência de $\mathrm{Mg}$ e redução da produção e do tamanho dos frutos. O objetivo deste trabalho foi verificar as relações da produção e peso dos frutos com os nutrientes das folhas e do solo de sete pomares de laranja Valência na safra de 1996/97, em talhões de produtividade inferior e superior. Em 1996, foram coletadas amostras de folha e de solo nas faixas de adubação e nas entrelinhas. Os resultados mostraram que a produção de frutos correlacionou-se negativamente com as relações dos cátions $\mathrm{Mg} / \mathrm{K}$ e $\mathrm{Ca}+\mathrm{Mg} / \mathrm{K}$ do solo das faixas de adubação dos pomares de baixa produtividade e, o peso dos frutos, correlacionou-se positivamente com os teores foliares de $\mathrm{Zn}$. Nos pomares de produtividade superior, o peso dos frutos correlacionou-se positivamente com os teores de $\mathrm{Ca}$ das folhas e do solo nas faixas de adubação. Estes resultados sugerem um manejo adequado da calagem e da adubação potássica nas faixas de adubação dos pomares de baixa produtividade e um adequado suprimento de $\mathrm{Zn}$.

\section{REFERENCES}

Boaretto, A. E.; Muraoka, T. ; Rêgo, I. C. (1996), Calagem e gessagem em citricultura. In: SEMINÁRIO INTERNACIONAL DE CITROS, 4, Bebedouro, 1996. Anais... Campinas: Fundação Cargill, 1996. 115-129

Embrapa. (1984), Serviço Nacional de Levantamento e Conservação de Solos. Levantamento de reconhecimento dos solos do estado do Paraná. Londrina: EMBRAPA-SNLCS/SUDESUL/IAPAR, 1/2: 791. (EMBRAPA. Boletim de Pesquisa, 27; IAPAR, Boletim Técnico, 16)

Fidalski, J. (1997), Fertilidade do solo sob pastagens, lavouras anuais e permanentes na região noroeste do Paraná. Revista Unimar, 19, 853-861

Fidalski, J.; Auler, P. A. M. (1997), Levantamento nutricional de pomares de laranja no noroeste do Paraná. Arq. Biol. Tecnol., 40, 443-451

Fidalski, J.; Pavan, M. A.; Auler, P. A. M.; Jacomino, A. P. (1999a), Produção de frutos de laranjeira Pêra e teores de nutrientes nas folhas e no solo, em Latossolo Vermelho-Escuro do noroeste do Paraná. $R$. Bras. Ci. Solo, 23, 273-279

Fidalski, J.; Auler, P. A.; Pavan, M. A.; Jacomino, A. P. (1999b), Manejo das entrelinhas e nutrição da laranja Pêra, em Latossolo Vermelho-Escuro do noroeste do Paraná. [cd-rom] In: CONGRESSO BRASILEIRO DE CIÊNCIA DO SOLO, 27., Brasília, 1999. Brasília: EMBRAPA. CNPAC, 1999

Grupo Paulista de Adubação e Calagem para Citros GPACC (1994), Recomendações de adubação e calagem para citros no Estado de São Paulo. 3ed. Laranja, Edição Especial, Cordeirópolis. 27p

Malavolta, E.; Violante Netto, A. (1989), Nutrição mineral, calagem, gessagem e adubação dos citros. Piracicaba: POTAFOS. $153 \mathrm{p}$

Malavolta, E.; Prates, H. S. (1994), Seja doutor de seu citros. Informações Agronômicas. Piracicaba: POTAFOS, 65, 1-16. (Arquivo do Agrônomo, 4)

Miyazawa, M.; Pavan, M. A.; Bloch, M. F. (1992), Análise química de tecido vegetal. Londrina: IAPAR. 17p. (IAPAR. Circular, 74)

Pavan, M. A.; Bloch, M. F.; Zempulski, H. C.; Miyazawa, M.; Zocoler, D. C. (1992), Manual de análise química do solo e controle de qualidade. Londrina: IAPAR. 40p. (IAPAR. Circular 76)

Quaggio, J. A. (1996), Análise de solo para citros: métodos e critérios para interpretação de resultados. In: SEMINÁRIO INTERNACIONAL DE CITROS, 4, Bebedouro, 1996. Anais... Campinas: Fundação Cargill, 1996. 95-113

Statical Analyseis Sistems Institute Inc. - SAS (1990), Procedure Guide, Version 6, Third Edition. Cary, NC: SAS Institute Inc,. 705p

Secretaria de Estado da Agricultura e do Abastecimento - SEAB (1999), Acompanhamento da Situação Agropecuária do Paraná, 25, 1-91
Received: December 17, 1998; Revised: February 17, 2000; Accepted: April 07, 2000. 